\title{
Inheritance and Characterization of a Glabrous Trait in Summer Squash
}

\author{
Qiubin Xiao \\ Department of Horticulture, Tokyo University of Agriculture and Technology, Tokyo, Japan \\ J. Brent Loy ${ }^{1}$ \\ Department of Plant Biology, University of New Hampshire, Durham, New Hampshire 03824
}

\begin{abstract}
AdDitional INDEX words. Cucurbita pepo, trichome, nonglabrous, spineless, anatomy, morphology
Abstract. This study was undertaken to determine the inheritance of a glabrous trait discovered in yellow straightneck summer squash (Cucurbita pepo L.) in 1992 and to compare trichome distribution and anatomy and morphologic features that relate to productivity in glabrous and nonglabrous genotypes. Inheritance data from 1994, 2003, and 2004 confirm that the glabrous trait is inherited as a single gene recessive, designated $g l-2$, but that in some segregating $\mathrm{F}_{2}$ populations with a zucchini or caserta $(C$. pepo ssp. pepo) background, there is a deficiency of glabrous segregants. Nonglabrous (NG) plants bore numerous trichomes on stems, petioles, leaf blades, and fruit. Trichomes were simple (unbranched), and most were either conical and unicellular or small filiform and multicellular (two to five cells). However, some larger multicellular trichomes with compound feet were found on major leaf blade veins and along vein tracts of petioles. Large, multicellular trichomes with compound feet were only occasionally present on leaf blades and petioles of glabrous (G) plants, and other trichome types were much reduced. This reduction gives fruit and foliage a smooth, waxy feel and largely eliminates trichome damage to fruit and skin irritation to workers during harvesting. Leaf number, staminate to pistillate flower ratios, and fruit size were not significantly different between glabrous $(g l-2 / g l-2)$ and nonglabrous $(G l-2 / g l-2)$ backcross (BC) genotypes. In one of two BC populations, pistillate flowering was $2 \mathrm{~d}$ earlier in NG as compared with $\mathrm{G}$ plants. The glabrous gene reduced the size of leaf blades in two BC populations; however, differences in total leaf areas were not statistically significant at $P=0.05$. A comparison of leaf numbers and size among $G$ and $N G$ parental plants and reciprocal $F_{1}$ hybrids derived from three separate crosses did not reveal a consistent effect of the $g l-2$ gene on plant morphology. Earliness and productivity of the best glabrous hybrids were similar to that of popular commercial cultivars.
\end{abstract}

Trichomes are epidermal hairs found on the surface of nearly all plants. They are used widely in plant taxonomy. Trichome initiation is an early event in leaf organogenesis first characterized by epidermal cell enlargement and then outgrowth and extension perpendicular to the leaf surface (Hülskamp et al., 1994; Szymanski et al., 1999). Depending on trichome type, branching and further growth may occur. Possible functions attributed to trichomes include modulation of temperature, water loss and photosynthesis through changes in light reflection (Kelsey, 1984), and deterrence of insect herbivores through glandular secretions and entrapment (Eisner et al., 1998; Kennedy and Sorenson, 1985; Khan et al., 1986; Lamb, 1980; Levin, 1973; Wagner, 1991).

In Cucurbitaceae, trichomes have a variety of shapes and sizes and may either be unicellular or multicellular, branched or unbranched, and glandular or nonglandular (Inamdar et al., 1990). Trichomes are most apparent on petioles, stems, and the underside of leaves, but finer hairs are also present on flowers, fruit, and the upper surface of leaves. Because of the often prickly nature of trichomes in Cucurbita L., they are commonly called spines and glabrous variants labeled as spineless. However, botanically, the term spine is correctly applied to woody outgrowths of stems representing modified plant organs (Featherly, 1954). In summer squash (Cucurbita pepo), trichomes are an undesirable anatomic trait because they can

Received for publication 28 Sept. 2005. Accepted for publication 24 Jan. 2007. Scientific contribution No. 2281 from the New Hampshire Agricultural Experiment Station.

${ }^{1}$ Corresponding author. E-mail: jbloy@cisunix.unh.edu. cause extensive abrasion of fruit during windy weather and harvesting, and also, the prickly trichomes on most cultivars can irritate the skin of field workers. Trichomes are especially large and abundant on cultivars of yellow straightneck and crookneck squash within C. pepo ssp. ovifera (L.) Decker.

Mutations affecting either the presence or absence of trichomes or their development have been found in several plant species (Reeves, 1977; Robinson, 1978; Singh et al., 1971), but the most extensive array of trichome mutants has been studied in Arabidopsis thaliana (L.) Heynh. (Hülskamp et al., 1994; Marks, 1997). Some trichome mutants have been shown to display pleiotropic effects on other aspects of plant development (Koornneef, 1981; Larkin et al., 1996; Robinson, 1978). Few mutations affecting trichome density have been reported in the genus Cucurbita. Holton (1980) reported differences in trichome density among zucchini breeding lines of summer squash. 'Spineless Beauty' and other so-called spineless cultivars of zucchini squash have been introduced by seed companies in recent years. Korzeniewska (1992) reported a single-gene recessive glabrous mutant $(g l)$ in Cucurbita maxima Duch. ex Lam. A semidominant glabrous mutant (designated as spineless) in yellow summer squash was registered to T. H. Superak under U.S. Patent 5,959,184 (Superak, 1999). In 1992, a glabrous mutant was discovered by J.B. Loy in an open pollinated cultivar of yellow straightneck squash. Initial segregation data supported single-gene, recessive inheritance. Some undesirable pleiotropic traits appeared to be associated with the glabrous mutation such as slower plant growth, a higher proportion of misshapen fruit, and precocious opening of the corolla. With crossing and selection 
over the past 14 years, the undesirable traits appear to have been either eliminated or reduced, but there have been no comparative studies to document the effect of the glabrous trait on trichome distribution in different organs and its effect on growth and development of summer squash. This study was undertaken to more thoroughly determine inheritance of the glabrous trait, to undertake a comparative anatomic study of the epidermal surface of leaves, petioles, and fruit of glabrous and nonglabrous genotypes, and to compare morphologic features in glabrous and nonglabrous genotypes that relate to productivity.

\section{Materials and Methods}

Growing Conditions. Plants were grown during the summers of 2002 and 2003 in research plots at the Woodman Horticultural Research Farm in Durham, N.H. (Charlton fine sandy loam, Inceptisol) and in 2004 at the Kingman Research Farm in Madbury, N.H. (Hollis-Charlton sandy loam, mixed, mesic, Entic Lithic Haplorthods). Research plots used raised beds ( $\approx 15 \mathrm{~cm}$ high $\times 60 \mathrm{~cm}$ wide) covered with $38.1-\mu \mathrm{m}$-thick black plastic mulch and provided with drip irrigation $(203.2 \mu \mathrm{m}$ T-tape with 30-cm emitter spacing; T-Systems International, San Diego). Plants were spaced $0.6 \mathrm{~m}$ apart. Before bed formation and mulching, fertilizer was broadcast at the rate of $56.2 \mathrm{~kg} \cdot \mathrm{ha}^{-1} \mathrm{~N}$ and $46.6 \mathrm{~kg} \cdot \mathrm{ha}^{-1} \mathrm{~K}$. Beginning $\approx 1$ week before flowering and continuing until experiments were ended, plants were fertigated once per week with $5.6 \mathrm{~kg} \cdot \mathrm{ha}^{-1} \mathrm{~N}, 0.24 \mathrm{~kg} \cdot \mathrm{ha}^{-1}$ $\mathrm{P}$, and $4.7 \mathrm{~kg} \cdot \mathrm{ha}^{-1} \mathrm{~K}$ using a soluble $20 \mathrm{~N}-0.87 \mathrm{P}-16.6 \mathrm{~K}$ formulation. Weed control between beds was provided by cultivation and some hand hoeing. Insect and disease control followed the recommendations given in the 2002-2003 New England Vegetable Management Guide (Howell et al., 2002). In 2003, beds were seeded on 6 June. For the 2004 inheritance study, seeds were sown during the second week of June, and for the 2004 morphologic study, seeding was on 16 July and leaf data were recorded on $17 \mathrm{Aug}$.

INHERITANCE STUDIES. Two reciprocal BC populations of yellow straightneck squash and nine $F_{2}$ populations of zucchini and caserta were used for 2003 inheritance studies at the Woodman Horticultural Farm. The BC populations segregating for glabrous and heterozygous nonglabrous plants were backcross \#1: $(\mathrm{NH} 139 \times \mathrm{NH} 21-15 \mathrm{G}) \times \mathrm{NH} 21-12-16 \mathrm{G}$ $\left(\mathrm{S}_{4}\right)$ and backcross \#2: NH219-5191G $\left(\mathrm{S}_{5}\right) \times(\mathrm{NH} 41-1 \times$ NH219-5191G). The NH21 glabrous (G) lines were derived from two backcrosses to the nonglabrous (NG) inbred NH139, and the NH219-5191G line was derived from two backcrosses to the recurrent NG inbred NH41-1. The $F_{2}$ populations were generated from crosses of $\mathrm{NG}$ and $\mathrm{G}$ inbred breeding lines followed by self-pollination of the $F_{1}$ hybrids. All pollinations used standard controlled pollination techniques for cucurbits as described by Robinson and Decker-Walters (1997). For BC populations, one seed was sown per hole. For $\mathrm{F}_{2}$ populations, three seeds per hole were used because NG plants were eventually rogued from the populations. Glabrous and NG genotypes were recorded at approximately the sixth leaf stage of growth both visually and by running fingers along the petioles of mature leaves. The latter method was needed in some populations for separating smooth $G$ plants from other zucchini plants segregating for a more abrasive feeling $G$ phenotype. In plants carrying the $\mathrm{G}$ trait characteristic of 'Spineless Beauty' and some black zucchini lines, the surface of petioles feels slightly abrasive.
In 2004, data were collected from four segregating $\mathrm{F}_{2}$ populations grown at the Kingman Research Farm in the same breeding plot used for the morphologic study described in the following section. All four segregating populations involved crosses between $\mathrm{NG}$ and $\mathrm{G}$ zucchini and caserta breeding lines.

Morphologic AND anAtomic studies. Using G and NG segregants in the $\mathrm{BC}$ populations, data were recorded on number of leaves per plant on four dates (14 July, 21 July, 4 Aug., and 31 Aug.) and dates when staminate and pistillate flowers first reached anthesis. Staminate and pistillate flowering over time was recorded for $16 \mathrm{G}$ and $10 \mathrm{NG}$ plants from each of the backcross populations over an 18-d period. Fruit size (diameter and length) at $3 \mathrm{~d}$ after anthesis was determined from measurements of 12 fruit per genotype for each backcross. Leaf blade measurements (width and length) were made on every other node up to the 24th node using five randomly chosen plants per genotype for each backcross. Approximate leaf areas were calculated by multiplying maximum width $\times$ length of leaf blades.

For anatomic studies, epidermal peels of leaf blades, petioles, and fruit were observed with a stereomicroscope. Semipermanent epidermal peels were made using the following procedure with Super Glue (Henkel Consumer Adhesive, Avon, Ohio): An epidermal peel was placed on a microscope slide and one drop of Super Glue was added onto the leaf surface. A cover glass was placed over the section and gently pressed down for $\approx 20 \mathrm{~s}$. After $\approx 30 \mathrm{~min}$, cover glasses were carefully peeled from leaves and the epidermal imprints observed. The method for making fruit epidermal peels was similar with the exception that one thin fruit slice was used for the epidermal peel. Observations of trichome anatomy were made with an Olympus SZ40 stereo microscope (Olympus America, Melville, N.Y.) and photomicrographs obtained with an attached Minolta Maxxum 7000 35-mm camera (Minolta Corp., Ramsey, N.J.).

For the 2004 morphologic study, four plant genotypes were compared in three separate populations: homozygous $\mathrm{NG}$ plants, homozygous $\mathrm{G}$ plants, $\mathrm{G} \times \mathrm{NG}$ nonglabrous $\mathrm{F}_{1}$ plants, and reciprocal $N G \times G$ nonglabrous $F_{1}$ plants. The NG and G parental lines making up the three populations were as follows: 1) NH41-1 and NH219-5191G, 2) NH231 and NH21-12-16G, and 3) NH231 and NH228-314-12G. NH231 is a NG sister line to $\mathrm{NH} 139 . \mathrm{NH} 228-314-12 \mathrm{G}$ is a $\mathrm{F}_{5}$ line derived from a cross of NH139 to a yellow straightneck G line. The three separate populations were grown in adjacent plots using randomized, complete block designs with either five or six blocks. Leaf numbers and leaf blade size were recorded after 32 d. Data were analyzed by analysis of variance using Microsoft Excel (Microsoft Corp., Redmond, Wash.).

\section{Results and Discussion}

INHERITANCE STUDIES. The G trait was discovered in a small plot of 'Yellow Prolific Straightneck' squash, the seed of which is believed to have been purchased from Willhite Melon Seed Farms some years before the planting. Two of the six plants in the small population showed the $G$ trait. One of the $N G$, self-pollinated plants from the segregating population (designated YSN5) segregated for G and NG plants in 1993. Two $\mathrm{S}_{2}$ selections were obtained from this population, YSN5-3, homozygous for the G trait, and YSN5-5, later shown to be heterozygous for the $G$ trait. In 1994, inheritance data on the 
Table 1. Inheritance of the glabrous trait in Cucurbita pepo summer squash in field studies conducted in 1994, 2003 , and 2004.

\begin{tabular}{|c|c|c|c|c|c|}
\hline \multirow[b]{2}{*}{ Crosses } & \multicolumn{2}{|c|}{ Phenotypes $^{\mathrm{z}}$ (no. of plants) } & \multirow[b]{2}{*}{ Expected ratios } & \multirow[b]{2}{*}{$\chi^{2}$} & \multirow[b]{2}{*}{$P$} \\
\hline & NG & $\mathrm{G}$ & & & \\
\hline \multicolumn{6}{|l|}{1994 populations $^{y}$} \\
\hline$(\mathrm{GACN} \times \mathrm{YSN} 5-3 \mathrm{G}) \times(\mathrm{SD} \times \mathrm{YSN} 5-3 \mathrm{G})$ & 82 & 19 & $3: 1$ & 2.06 & $0.16-0.12$ \\
\hline$(\mathrm{SD} \times \mathrm{YSN} 5-3 \mathrm{G}) \otimes$ & 60 & 29 & $3: 1$ & 2.73 & $0.14-0.10$ \\
\hline$(\mathrm{GACN} \times \mathrm{YSN} 5-3 \mathrm{G}) \otimes$ & 67 & 21 & $3: 1$ & 0.06 & $0.90-0.80$ \\
\hline Combined & 346 & 116 & $3: 1$ & 0.003 & $1.00-0.95$ \\
\hline \multicolumn{6}{|l|}{2003 backcross populations ${ }^{x}$} \\
\hline$(\mathrm{SM} 139 \times 21-15 \mathrm{G}) \times 21-12-16 \mathrm{G}$ & 48 & 43 & $1: 1$ & 0.27 & $0.65-0.55$ \\
\hline $21-12-16 \mathrm{G} \times(\mathrm{SM} 139 \times 21-15 \mathrm{G})$ & 38 & 41 & $1: 1$ & 0.11 & $0.80-0.70$ \\
\hline \multicolumn{6}{|l|}{$2003 F_{2}$ populationsw } \\
\hline$(118-21-4 \times B 1 R 2-14 G) \otimes$ & 95 & 25 & $3: 1$ & 1.11 & $0.35-0.25$ \\
\hline$(40-16 \mathrm{G} \times \mathrm{AST}) \otimes$ & 136 & 39 & $3: 1$ & 0.69 & $0.45-0.35$ \\
\hline$(118-101-3 \times 66-1 G) \otimes$ & 245 & 64 & $3: 1$ & 3.03 & $0.09-0.08$ \\
\hline$(118-150-28 \times 40-6 \mathrm{G}) \otimes$ & 312 & 67 & $3: 1$ & 10.84 & $<0.002$ \\
\hline$(B 1 R 5-6 G \times 118-150-13) \otimes$ & 70 & 25 & $3: 1$ & 0.09 & $0.80-0.70$ \\
\hline \multicolumn{6}{|l|}{$2004 F_{2}$ populationsw } \\
\hline$(\mathrm{B} 1 \mathrm{R} 2-14 \mathrm{G} \times 118-12-4) \otimes$ & 155 & 25 & $3: 1$ & 11.85 & $<0.001$ \\
\hline$(40-16 \mathrm{G} \times \mathrm{AST}) \otimes$ & 95 & 42 & $3: 1$ & 2.33 & $0.15-0.10$ \\
\hline$(\mathrm{CAS} 4-1 \times \mathrm{B} 1 \mathrm{R} 11-3 \mathrm{G}) \otimes$ & 138 & 41 & $3: 1$ & 0.34 & $0.60-0.50$ \\
\hline$(118-12-4 \times 40-15 G) \otimes$ & 148 & 22 & $3: 1$ & 13.19 & $<0.001$ \\
\hline Homogeneity (all 2003-2004 $\mathrm{F}_{2}$ populations) & & & & 28.60 & $<0.005$ \\
\hline
\end{tabular}

${ }^{\mathrm{z}} \mathrm{NG}=$ nonglabrous; $\mathrm{G}=$ glabrous.

${ }^{y}$ Only one G yellow straightneck (YSN) line, YSN5-3 $\left(\mathrm{S}_{2}\right)$, used in all crosses. SD = 'Sundance' $\mathrm{F}_{1}$ hybrid; GACN = 'Golden Arches Yellow Crookneck'; 38-2 = NG YSN breeding line.

${ }^{\mathrm{x}} \mathrm{NG}\left(\mathrm{SM} 139\right.$ inbred) and $\mathrm{G}\left(\mathrm{NH} 21-15 \mathrm{~F}_{3}\right)$ YSN breeding lines.

${ }^{\mathrm{w}} \mathrm{NG}$ and $\mathrm{G}$ zucchini and caserta breeding lines.
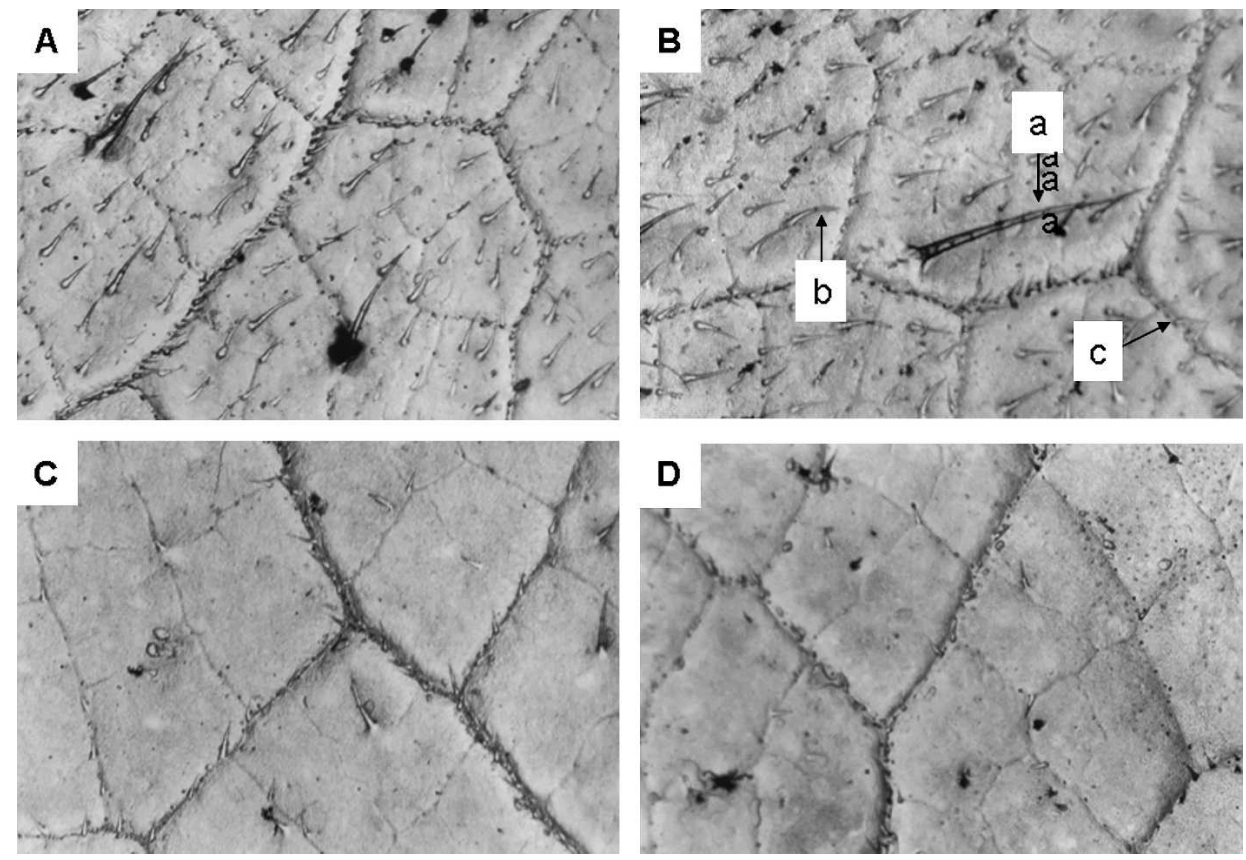

Fig. 1. Abaxial (lower) leaf blade surfaces of two nonglabrous (NG) and two glabrous (G) genotypes in Cucurbita pepo. (A) A NG segregant from the backcross population $(41-1 \times 5191 \mathrm{G}) \times 219-5191 \mathrm{G}$. (B) A NG segregant from original mutant population (YSN-5-5). (C) A G segregant from the backcross population $(139 \times 21-15 \mathrm{G}) \times$ 21-12-18G. (D) A G plant derived from original mutant selection (YSN5-3). Magnification is $15 \times$.
$\mathrm{G}$ trait were obtained from three $\mathrm{F}_{2}$ populations and one $F_{1} \times F_{1}$ cross using YSN5-3 as the G parent in crosses. Segregation for the $G$ trait in all four populations fit a $3: 1$ ratio expected for a simple recessive trait (Table 1). However, no reciprocal crosses or backcrosses were made and examined closely during this period. Observations among segregating populations suggested that $G$ plants tended to be less vigorous than NG plants. In addition, a flowering anomaly associated with the $\mathrm{G}$ gene was the precocious, partial opening of pistillate flowers $1 \mathrm{~d}$ preanthesis.

Backcross data obtained in 2003 from reciprocal crosses among yellow straightneck lines also supported single, recessive gene inheritance (Table 1). However, $F_{2}$ segregation patterns for the $G$ gene introgressed into populations of zucchini and caserta squash occasionally showed deficiencies in $\mathrm{G}$ segregants in both 


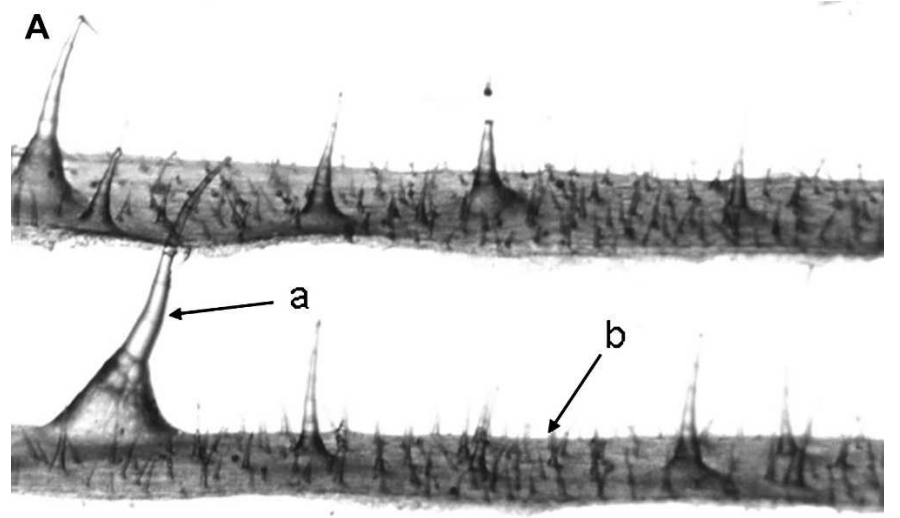

B

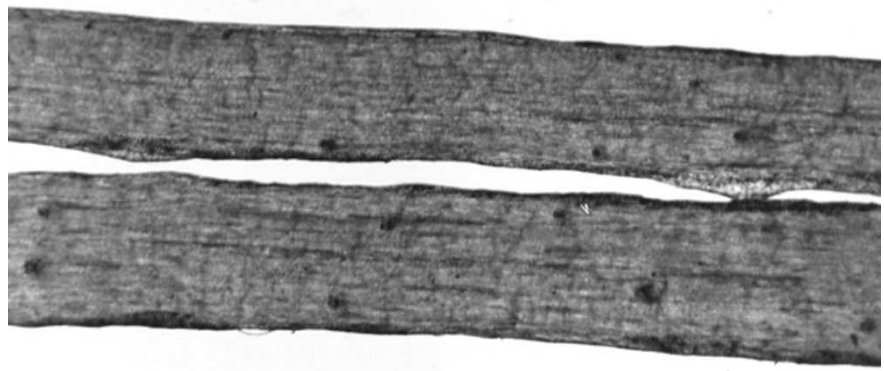

Fig. 2. Petiole surface of a nonglabrous (A) plant derived from the original mutant $\mathrm{S}_{2}$ segregating line (YSN5-5) and a glabrous (B) plant derived from the original $\mathrm{S}_{2}$ mutant line (YSN5-3) in Cucurbita pepo. Magnification is $15 \times$.

2003 and 2004. In four of 13 populations, segregation failed to conform to a 3:1 ratio according to $\chi^{2}$ values. In 2004, both of the populations showing a deficiency of $\mathrm{G}$ segregants involved the NG parental line, NH118-12-4. We have not investigated possible causes of this segregation distortion, but segregation distortion was previously reported in C. pepo for the fused vein trait $(f v)$ and was found to be at least in part incited by slower growth of pollen tubes carrying the $f v$ allele (Carl and Loy, 1996).

Reduced presence of trichomes in summer squash has been reported previously. In a study of trichome density in breeding lines of summer squash, Holton (1980) observed 24.25 trichomes per $10 \mathrm{~cm}$ of petiole length in one parent and only 1.68 in a second parent. The presence of trichomes was dominant to reduced number of trichomes; however, trichome length appeared to be partially dominant. Segregation in $F_{2}$ populations suggested multigenic inheritance. No mention is made of glossy or smooth-textured petioles and stems associated with the reduced spines in Holton's material, and it is presumed that she was working with the type of $G$ trait associated with 'Spineless Beauty' and known to exist in some of the black zucchini germplasm. In C. maxima, Korzeniewska (1992) reported a single recessive gene conferring the G trait, which was designated $g l$. We suggest that the gl mutant in C. maxima be designated $g l-1$ and that the $\mathrm{G}$ mutant described in this article be designated $g l-2$. The semidominant $\mathrm{G}$ gene described by Superak (1999) in C. pepo is phenotypically distinct from $g l-2$, lacking the smooth glossy feel of $g l-2$ petioles. We have crossed line G-19, carrying the semidominant G gene, to NH219-5191, homozygous for $g l-2$. The eight $\mathrm{F}_{1}$ plants
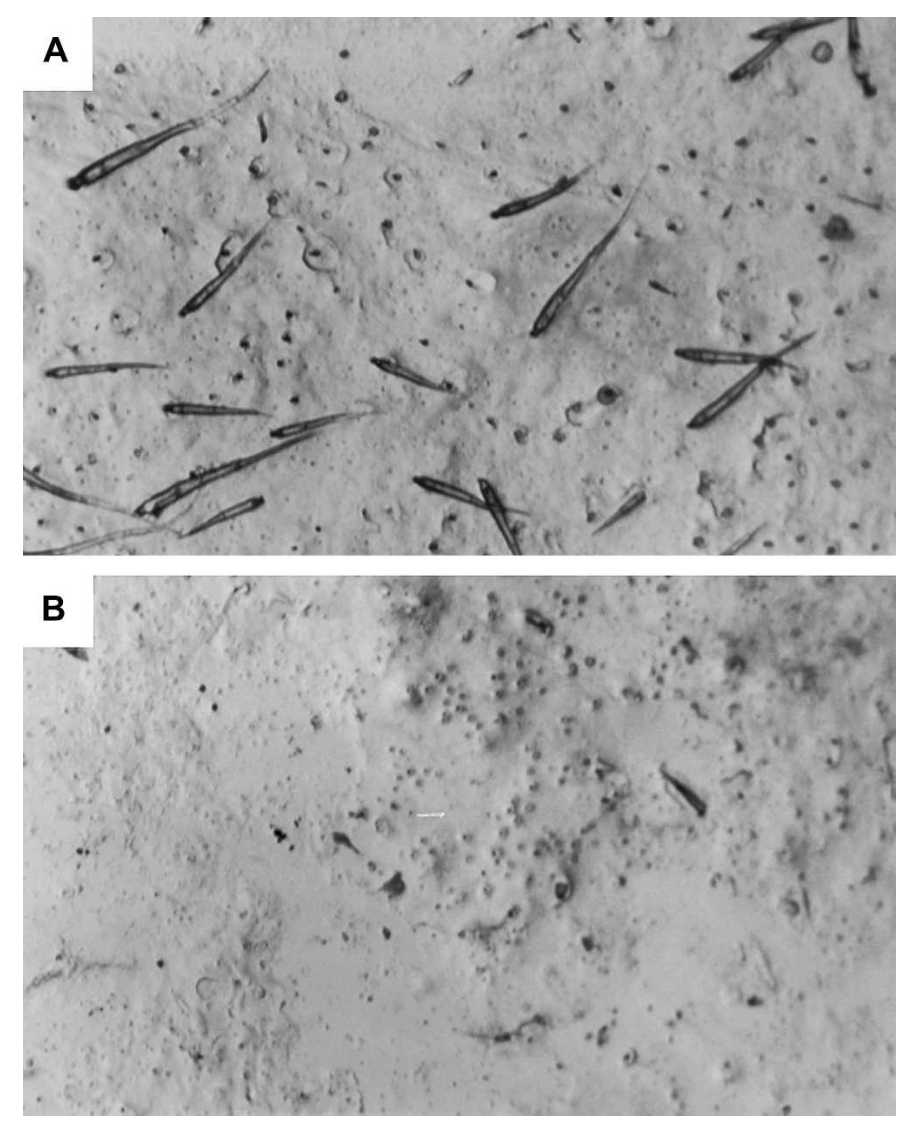

Fig. 3. Fruit surface of a nonglabrous genotype (A) from the backcross population $(139 \times 21-15 \mathrm{G}) \times 21-12-18 \mathrm{G}$ and a glabrous genotype $(\mathbf{B})$ derived from the original mutant $\mathrm{S}_{2}$ line (YSN5-3) in Cucurbita pepo. Magnification is $15 \times$.

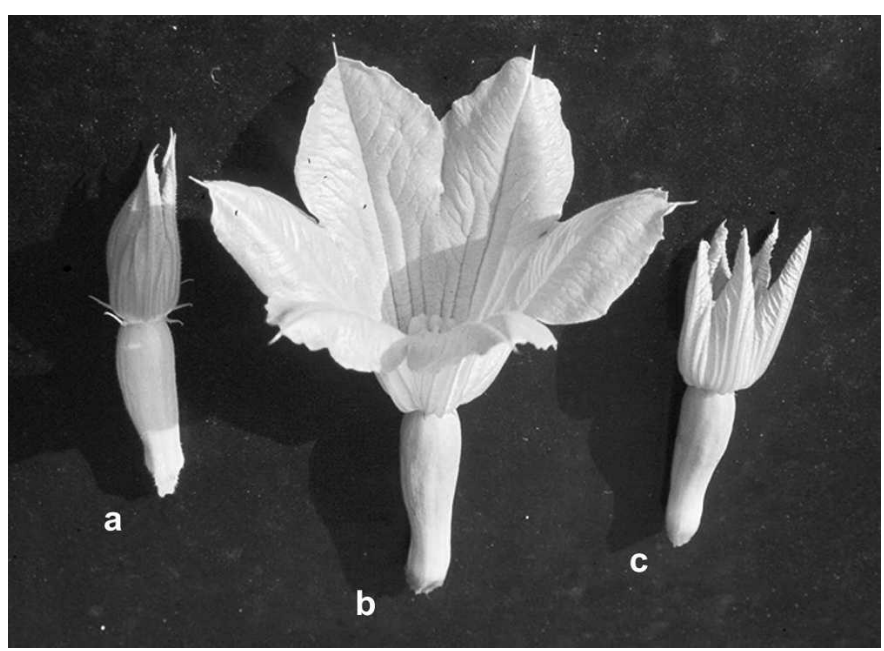

Fig. 4. A normal pistillate flower bud (A) and a precociously opened flower bud (C) $24 \mathrm{~h}$ before anthesis and a normal pistillate flower at anthesis (B) obtained from glabrous yellow straightneck squash hybrids (Cucurbita pepo).

examined exhibited numerous trichomes on leaf blades and petioles, indicating that the two mutant genes are nonallelic. We suggest that the $\mathrm{G}$ gene reported by Superak be designated as $\mathrm{Gl}-3$.

Anatomic Differences. Three types of conical trichomes occurred on leaves of NG plants between the large veins (Fig. 1B): 1) long, filiform multicellular trichomes (a); 
Table 2. Comparison of mean leaf numbers, leaf widths, leaf lengths, and leaf areas between glabrous $(g l-2 / g l-2)$ and nonglabrous $(G l-2 / g l-2)$ segregants in two backcross populations of Cucurbita pepo after $86 \mathrm{~d}$ of growth in the field .

\begin{tabular}{lcccc}
\hline & $\begin{array}{c}\text { Leaves } \\
(\text { avg no. })^{\mathrm{z}}\end{array}$ & $\begin{array}{c}\text { Avg leaf } \\
\text { width }(\mathrm{cm})^{\mathrm{y}}\end{array}$ & $\begin{array}{c}\text { Avg leaf } \\
\text { length }(\mathrm{cm})^{\mathrm{y}}\end{array}$ & $\begin{array}{r}\text { Avg leaf } \\
\text { area }\left(\mathrm{cm}^{2}\right)^{\mathrm{y}}\end{array}$ \\
\hline $\begin{array}{c}\text { Backcross \#1 } \\
\text { Glabrous }\end{array}$ & $55.7 \mathrm{a}^{\mathrm{w}}$ & $37.3 \mathrm{a}^{\mathrm{w}}$ & $27.7 \mathrm{a}^{\mathrm{w}}$ & $1,035.3 \mathrm{a}^{\mathrm{w}}$ \\
$\begin{array}{c}\text { Nonglabrous } \\
\text { Backcross \#2 }\end{array}$ & $54.4 \mathrm{a}$ & $39.2 \mathrm{a}$ & $29.6 \mathrm{~b}$ & $1,160.2 \mathrm{a}$ \\
$\begin{array}{l}\text { Glabrous } \\
\text { Nonglabrous }\end{array}$ & $42.9 \mathrm{a}$ & $30.9 \mathrm{a}$ & $28.2 \mathrm{a}$ & $871.7 \mathrm{a}$ \\
\hline
\end{tabular}

${ }^{\mathrm{z}}$ Sample sizes were 13 glaborous and 10 nonglaborous plants for backcross \#1 and 14 glabrous and 10 nonglabrous plants for backcross \#2.

y Data are means of five plants per genotype and 12 leaves per plant from alternating nodes 2 through 24.

${ }^{\mathrm{x} B a c k c r o s s} \# 1=(\mathrm{NH} 139 \times \mathrm{NH} 21-15 \mathrm{G}) \times \mathrm{NH} 21-12-16 \mathrm{G} ;$ backcross $\# 2=\mathrm{NH} 219-5191 \mathrm{G} \times$ $(41-1 \times 5191 \mathrm{G})$.

wPaired comparisons within columns followed by the same letter are not significantly different at $P=0.05$ by analysis of variance.

Table 3. Comparison of time to first flower, staminate to pistillate flower ratios, and fruit shape between glabrous $(g l-2 / g l-2)$ and nonglabrous $(G l-21 / g l-2)$ segregants in two backcross populations of Cucurbita pepo.

\begin{tabular}{|c|c|c|c|c|c|}
\hline & \multicolumn{2}{|c|}{ Time to first flower $(\mathrm{d})^{\mathrm{z}}$} & \multicolumn{2}{|c|}{ Fruit shape $^{y}$} & \multirow[b]{2}{*}{$\mathrm{S} / \mathrm{P}^{\mathrm{z}}$ ratio } \\
\hline & $\mathrm{S}$ & $\mathrm{P}$ & Length $(\mathrm{cm})$ & $\overline{\operatorname{Diam}(\mathrm{cm})}$ & \\
\hline \multicolumn{6}{|l|}{ Backcross $\# 1^{\mathrm{x}}$} \\
\hline Glabrous & $46.1 \pm 1.1 \mathrm{a}^{\mathrm{w}}$ & $39.9 \pm 2.0 \mathrm{a}^{\mathrm{w}}$ & $15.8 \pm 1.3 \mathrm{a}^{\mathrm{w}}$ & $3.6 \pm 0.4 \mathrm{a}^{\mathrm{w}}$ & $1.7 \pm 0.4$ \\
\hline Nonglabrous & $45.8 \pm 0.9 \mathrm{a}$ & $38.5 \pm 1.6 \mathrm{a}$ & $14.9 \pm 2.3 \mathrm{a}$ & $3.7 \pm 0.5 \mathrm{a}$ & $1.4 \pm 0.2$ \\
\hline \multicolumn{6}{|l|}{ Backcross $\# 2^{\mathrm{x}}$} \\
\hline Glabrous & $44.8 \pm 1.6 \mathrm{a}$ & $40.6 \pm 2.1 \mathrm{a}$ & $13.8 \pm 2.5 \mathrm{a}$ & $3.7 \pm 0.7 \mathrm{a}$ & $3.1 \pm 0.9$ \\
\hline Nonglabrous & $44.7 \pm 0.9 \mathrm{a}$ & $37.9 \pm 1.4 \mathrm{~b}$ & $13.5 \pm 4.4 \mathrm{a}$ & $3.5 \pm 0.4 \mathrm{a}$ & $3.3 \pm 0.9$ \\
\hline
\end{tabular}

${ }^{\mathrm{z}}$ Staminate (S) and pistillate (P) flowers; time from seeding to first flower (d) for 16 glabrous and 10 nonglabrous plants each for backcross \#1 and backcross \#2.

yThe length and maximum diameter of 12 fruit per genotype were measured on the third day after anthesis.

${ }^{\mathrm{x} B a c k c r o s s} \# 1=(\mathrm{NH} 139 \times \mathrm{NH} 21-15 \mathrm{G}) \times \mathrm{NH} 21-12-16 \mathrm{G}$; backcross $\# 2=\mathrm{NH} 219-5191 \mathrm{G} \times$ $(41-1 \times 5191 \mathrm{G})$.

${ }^{w}$ Mean ( \pm standard deviation) comparisons within columns of glabrous and nonglabrous plants by analysis of variance. Paired comparisons followed by the same letter are not significantly different at $P=0.05$.

2) smaller, randomly dispersed, multicellular (two to three cells) trichomes (b); and 3) small unicellular trichomes (c). The larger trichomes were infrequent and randomly dispersed on the leaf blade, whereas unicellular trichomes were especially abundant along leaf veins. Only occasional large multicellular trichomes were present on the leaf surface of G plants, the small multicellular trichomes were infrequent, and most of the tiny unicellular trichomes occurred along minor leaf veins (Fig. 1C, D). Large, multicellular trichomes with multicellular feet were present on the main leaf veins (not shown) and contributed to the prickly nature of lower side of leaf blades.

The petiole surface of NG plants (Fig. 2A) displayed many large to moderately large conical multicellular trichomes with compound (multicellular) feet (a) and numerous smaller multicellar trichomes (b) with compound feet. Although not readily apparent in micrograph (Fig. 2A), the large multicellular trichomes and a majority of the small multicellular trichomes were localized along vein tracts. Only an occasional large trichome and a few small trichomes with single basal cells, almost totally confined to vein tracts, were observed on petioles of $G$ plants (Fig. 2B). As a result, the surface of $G$ petioles and stems exhibited a smooth, waxy feel. This contrasts with petioles of 'Spineless Beauty' zucchini, mostly devoid of trichomes, but which retain multicellular trichome feet that protrude from the epidermis, giving stems an abrasive feel (J. B. Loy, unpublished observations).

Numerous slender, conical trichomes, three to five cells in length, were observed on the fruit surface of NG plants (Fig. 3A), whereas trichome density was much reduced on fruit of G plants (Fig. 3B), and the fruit surface appeared slightly glossier. Trichome distribution on fruit appears to be random and not associated with underlying vasculature. The black dots seen on the epidermal peals of the fruit surface (Fig. 3A) are remnants of glandular trichomes.

In oil seed pumpkin (C. pepo), Kolb and Müller (2004) described four types of trichomes on leaf surfaces, three of which were glandular. The nonglandular type III corresponds to the multicellular, filiform trichomes depicted on the lower leaf surface in Figure 1B in our study. Glandular trichomes were not readily detected with the epidermal peals used in our study 
but could be easily observed in fresh sections. The glandular trichomes were mostly either short-stalked $(40$ to $70 \mu \mathrm{m})$ or long-stalked (130 to $180 \mu \mathrm{m})$ with single basal cells. In contrast, the large trichomes on petioles and major leaf veins of summer squash that contribute to their prickly nature are typically 1.0 to $2.0 \mathrm{~mm}$ long with thick basal, multicellular feet $(0.5$ to $1.0 \mathrm{~mm}$ wide). Most nonglandular trichomes or hairs on the fruit surface, although 0.4 to $1.2 \mathrm{~mm}$ in length, were slender and not objectionably abrasive to the feel.

There is sparse reference in the literature to preferential association of trichomes along vascular tracts as we have noted in C. pepo. However, the type II glandular trichome in C. pepo described by Kolb and Müller (2004) was most frequent on leaf veins, and Gómez-Guillamón et al. (2006) observed in melon that two types of glandular trichomes were mostly located on leaf veins.

Morphologic Differences. Overall growth habits and phenotypes of $\mathrm{NG}$ and $\mathrm{G}$ plants were indistinguishable. Although foliage of $\mathrm{G}$ plants appears somewhat glossier than that of NG plants, it is not easy to discern this difference through photography. The foliage difference is most noticeable on newly unfolding leaf blades and petioles of $\mathrm{G}$ plants, which have a lighter, more yellowish green appearance than that of NG plants. In the original G mutant line (YSN5-3) and in some $\mathrm{G}$ breeding lines, corollas of pistillate flowers open partially $1 \mathrm{~d}$ before normal anthesis (Fig. 4). This anomaly occurs infrequently on most advanced breeding lines. Because the color of these precociously opened flowers is greenish yellow, bees do not visit them. If precocious pollination did occur, pistillate flowers would set fruit and develop normally if pollinated $1 \mathrm{~d}$ preanthesis.

There was no difference in main stem vegetative growth of $\mathrm{NG}$ and $\mathrm{G}$ plants as revealed from leaf counts for both $\mathrm{BC}$ populations (Table 2). Nonglabrous plants in both backcross populations had both longer and wider leaf blades than those of $G$ plants and therefore larger leaf areas (Table 2), but differences were statistically significant only for leaf width in backcross \#2 and leaf length in backcross \#1.

Time of appearance of first staminate and pistillate flowers, staminate to pistillate flower ratios, and fruit size did not differ between $\mathrm{NG}$ and $\mathrm{G}$ genotypes in the $\mathrm{BC}$ population \#1, but pistillate flowers appeared $2 \mathrm{~d}$ earlier in $\mathrm{NG}$ genotypes in the second backcross population (Table 3). Both $\mathrm{G}$ and $\mathrm{NG}$ genotypes in $\mathrm{BC}$ population \#2 had a higher ratio of staminate to pistillate flowers than did those in BC population \#1.

Using three different sets of parents and crosses, leaf number and size were compared in 2004 among three genotypes, an NG parent, a genetically related $G$ parent, and the reciprocal $F_{1}$ hybrids (Table 4). There were no consistent differences in leaf size and leaf number associated with different dosages of the $g l-2$ allele. In BC population \#2, leaf numbers were significantly higher in the NG parent than in either the G parent or the $\mathrm{F}_{1}$ hybrids. However, in $\mathrm{BC}$ population \#1, leaf numbers were significantly greater in the $\mathrm{G}$ line and in one of the two hybrids than in the NG line, but the differences were small. Leaf length in $\mathrm{BC}$ population \#1 was greater in the $\mathrm{NG}$ parent and $\mathrm{F}_{1}$ plants than in the $G$ parent. In $B C$ population \#3, leaf number was slightly higher in the NG line than in the $\mathrm{G}$ line but differed significantly from only one of the two hybrids. Thus, it appears that growth differences between $\mathrm{NG}$ and $\mathrm{G}$ genotypes are more likely to be associated with the overall genetic background of plants rather than by pleiotropic effects of the $g l-2$ gene.
Table 4. Comparison of leaf counts and width and length of leaf blades among a nonglabrous (NG) line, a glabrous (G) line, and reciprocal $\mathrm{F}_{1}$ plants in three separate populations of yellow straightneck summer squash (Cucurbita pepo).

\begin{tabular}{|c|c|c|c|}
\hline Genotype & $\begin{array}{c}\text { Leaves } \\
(\text { avg no. })^{z}\end{array}$ & $\begin{array}{c}\text { Avg leaf } \\
\text { width }(\mathrm{cm})^{\mathrm{y}}\end{array}$ & $\begin{array}{c}\text { Avg leaf } \\
\text { length }(\mathrm{cm})^{3}\end{array}$ \\
\hline \multicolumn{4}{|l|}{ Population $\# 1^{x}$} \\
\hline NH231 (NG) & 10.08 & 24.3 & 19.77 \\
\hline NH21-15 (G) & 10.92 & 23.9 & 17.51 \\
\hline NH231 × NH21-15 (NG) & 10.67 & 25.0 & 19.71 \\
\hline $\mathrm{NH} 21 \times 15 \times \mathrm{NH} 231(\mathrm{NG})$ & 10.58 & 25.1 & 19.66 \\
\hline LSD $_{0.05}$ & 0.54 & NS & 1.16 \\
\hline \multicolumn{4}{|l|}{ Population $\# 2^{x}$} \\
\hline NH41-1 (NG) & 10.10 & 18.39 & 18.10 \\
\hline NH5191 (G) & 7.90 & 19.82 & 19.78 \\
\hline NH41-1 × NH5191 (NG) & 8.40 & 18.29 & 17.16 \\
\hline NH5191 × NH41-1 (NG) & 8.50 & 21.41 & 20.80 \\
\hline LSD $_{0.05}$ & 0.88 & NS & 2.52 \\
\hline \multicolumn{4}{|l|}{ Population $\# 3^{x}$} \\
\hline NH231 (NG) & 11.33 & 27.09 & 21.72 \\
\hline NH228 (G) & 10.50 & 28.76 & 21.80 \\
\hline $\mathrm{NH} 231 \times \mathrm{NH} 228(\mathrm{NG})$ & 10.50 & 28.42 & 21.77 \\
\hline NH228 × NH231 (NG) & 11.00 & 29.89 & 23.09 \\
\hline LSD $_{0.05}$ & 0.52 & NS & NS \\
\hline
\end{tabular}

${ }^{\mathrm{z}}$ Leaf numbers recorded on 17 Aug., $32 \mathrm{~d}$ from seeding.

y Leaf dimensions taken from four most distal, fully expanded leaves. ${ }^{x}$ Randomized complete block designs with six replications for populations 1 and 3 and five replications for population 2 . $\mathrm{LSD}=$ least significant difference.

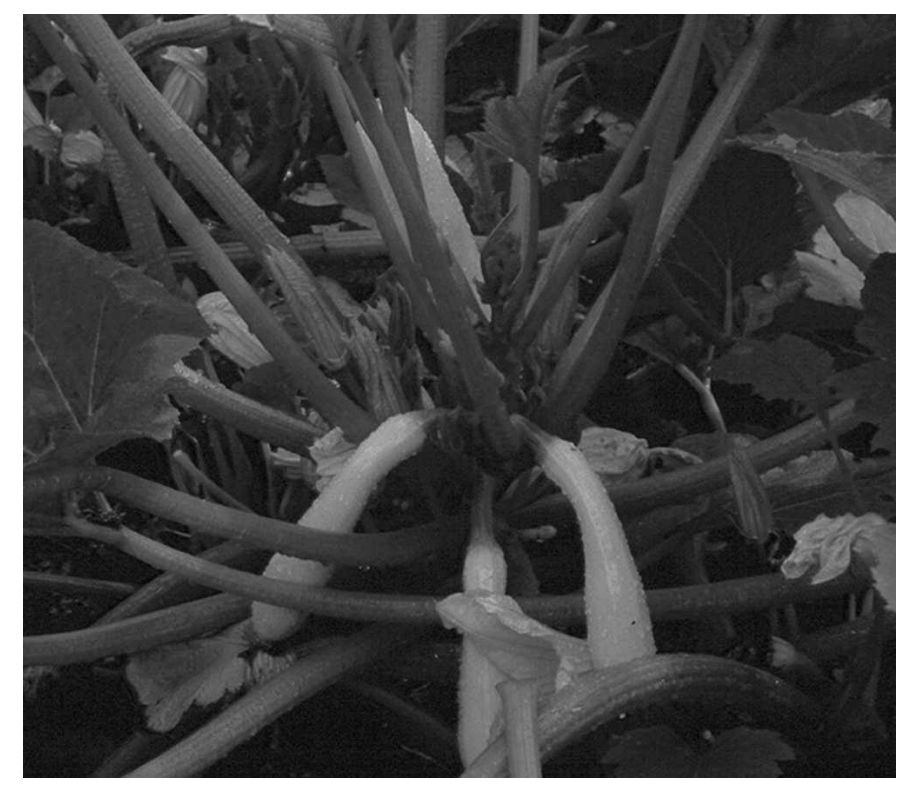

Fig. 5. Glabrous yellow straightneck hybrid NH260C (Cucurbita pepo) during stage of peak fruit production.

There may be a dosage effect of the $g l-2$ gene on trichome density or length as reported by Holton (1980) in comparing crosses and lines of spineless and spiny zucchini summer squash, but it likely will be necessary to develop isogenic lines to document such an effect. In comparing $\mathrm{F}_{1}$ plants derived from $\mathrm{NG} \times$ $\mathrm{G}$ crosses, and heterozygous for $g l-2$, with their $\mathrm{NG}$ parents in the 
previously mentioned morphologic study, plants were subjectively rated for relative trichome density. Homozygous $G l-2$ plants sometimes appeared to have more trichomes than the $\mathrm{F}_{1}$ hybrids, but the effect was not consistent among all three populations, and relative appearance of trichomes among individual plants varied as much within each genotype as between genotypes.

Productivity of F F $_{1}$ Hybrids. Several G, yellow straightneck inbred lines have been developed with a range of maturity, the bush and single stem plant habit, and appropriate elongate fruit type that is commercially acceptable. Several hybrids have been constituted from these inbreds and evaluated for yield and maturity in 2002, 2003, and 2004. In a comparison of two of the most productive $\mathrm{G}$ hybrids with two productive commercial cultivars, Superpik and Fortune, early and total yields were not significantly different (data not presented). The $G$ hybrid, $\mathrm{NH} 260 \mathrm{C}$, is currently in commercial production and is noteworthy for upright growth habit, lack of axillary branching, and long, slender fruit (Fig. 5). Seed samples of NH260C can be requested from Hollar Seeds, Rocky Ford, Colo.

\section{Literature Cited}

Carl, R.B. and J.B. Loy. 1996. Fused vein trait in Cucurbita pepo associated with subvitality of the male gametophyte. J. Amer. Soc. Hort. Sci. 121:18-22.

Eisner, T., M. Eisner, and E.R. Hoebeke. 1998. When defense backfires: Detrimental effect of a plant's protective trichomes on an insect beneficial to the plant. Proc. Natl. Acad. Sci. USA 95:4410-4414.

Featherly, H.I. 1954. Taxonomic terminology of the higher plants. Iowa State College Press, Ames, Iowa.

Gómez-Guillamón, M.L., A. Heredia, and E. Sarria. 2006. Epicuticular wax morphology and trichome types in relation to host plant selection by Aphis gossypii in melons, p. 108-115. In: G.J. Holmes (ed.). Cucurbitaceae 2006. Universal Press, Raleigh, N.C.

Holton, M.L. 1980. Inheritance of spininess in summer squash. University of California, Davis, MS Thesis.

Howell, J.C., A.R. Bonanno, J.J. Boucher, D.N. Ferro, and R.L. Wick. 2002. New England vegetable management guide. UMass Extension Office of Communications and Marketing, University of Massachusetts, Amherst.

Hülskamp, M., S. Misera, and G. Jürgens. 1994. Genetic dissection of trichome cell development in Arabidopsis. Cell 76:555-566.

Inamdar, J.A., M. Gangadhara, and K.N. Shenoy. 1990. Structure, ontogeny, organographic distribution, and taxonomic significance of trichomes and stomata in the Cucurbitaceae, p. 290-224. In: D.M.
Bates, R.W. Robinson, and C. Jeffrey (eds.). Biology and utilization of the Cucurbitaceae. Cornell University Press, Ithaca, N.Y.

Kelsey, R.G. 1984. The chemistry of biologically active constituents secreted and stored in plant glandular trichomes, p. 187-241. In: E. Rodriguez, P.L. Healey, and I. Mehta (eds.). Biology and chemistry of plant trichomes. Plenum Press, N.Y.

Kennedy, G.G. and C.F. Sorenson. 1985. Role of glandular trichomes in the resistance of Lycopersion hirsutum f. glabratum to colorado potato beetle (Coleoptera: Chrysomelidae). J. Econ. Entomol. 78: 547-551.

Khan, Z.R., J.T. Ward, and D.M. Norris. 1986. Role of trichomes in soybean resistance to cabbage looper, Trichoplusia ni. Entomol. Exp. Appl. 42:109-117.

Kolb, D. and M. Müller. 2004. Light, conventional and environmental scanning electron microscopy of the trichomes of Cucurbita pepo subsp. pepo var. styriaca and histochemistry of glandular secretory products. Ann. Bot. (Lond.) 94:515-526.

Koornneef, M. 1981. The complex syndrome of ttg mutants. Arabidopsis Info. Serv. 18:45-51.

Korzeniewska, A. 1992. New genes in Cucurbita maxima Duch. p. 75-78. In: R.W. Doruchowski and K. Niemirowicz-Szczytt (eds.). Fifth Eucarpia Cucurbitaceae Symposium, SkierniewiceWarsaw, Poland.

Lamb, R. 1980. Hairs protect pods of mustard (Brassica hirta 'gisilba') from flea beetle feeding damage. Can. J. Plant Sci. 60:1439-1440.

Larkin, J.C., N. Young, M. Prigge, and D.M. Marks. 1996. The control of trichome spacing and number in arabidopsis. Development 122:991-1005.

Levin, D.A. 1973. The role of trichomes in plant defense. Q. Rev. Biol. 48:3-15.

Marks, D.M. 1997. Molecular genetic analysis of trichome development in arabidopsis. Annu. Rev. Plant Physiol. 48:137-163.

Reeves, A.F. 1977. Tomato trichomes and mutations affecting their development. Amer. J. Bot. 64:186-189.

Robinson, R.W. 1978. Pleiotropic effects of the glabrous gene of the cucumber. Cucurbit Genet. Coop. Rpt. 1:14.

Robinson, R.W. and D.S. Decker-Walters. 1997. Cucurbits. CAB International, N.Y.

Singh, B.B., H.H. Hadley, and R.L. Bernard. 1971. Morphology of pubescence in soybeans and its relations to plant vigor. Crop Sci. 11:13-16.

Superak, T.H. 1999. Plants and seeds of Cucurbita pepo having a genetic factor for spinelessness. U.S. Patent No. 5,959,184 (28 Sept. 1999). U.S. Patent and Trademark Office, Washington, D.C.

Szymanski, D.B., M.D. Marks, and S.M. Wick. 1999. Organized F-actin is essential for normal trichome morphogenesis in Arabidopsis. Plant Cell 11:2331-2347.

Wagner, G.J. 1991. Secreting glandular trichomes: More than just hairs. Plant Physiol. 96:675-679. 